(C) Яковенко В.В., 2019 p.

http://orcid.org/0000-0003-3826-037X

DOI: $10.34142 / 23128046.2019 .46 .15$

В. В. Яковенко

\title{
ПІДГОТОВКА ДОШКІЛЬНИХ ПРАЦІВНИКІВ ДО ОРГАНІЗАЦЇ̈ ТРУДОВОГО ВИХОВАННЯ ДІТЕЙ (КІНЕЦЬ ХІХ - ПЕРША ПОЛОВИНА ХХ СТ.)
}

У статті проаналізовано чинники, які вплинули на підготовку дошкільних працівників до організачиї трудового виховання дітей у період кіния XIX - першої половини XX століття. 3'ясовано, щзо окремі теоретичні й методичні аспекти зазначеної проблеми розкрито в працях науковців. Так, питання наступності трудового виховання дітей дошкільного та молодшого шкільного віку вивчали А. Богуш, 3. Борисова, Г. Люблінська, М. Машовецьь, О. Проскура, О. Савченко; різні аспекти розвитку дошкільного виховання та початкової иколи досліджували Н. Антонецьь, О. Барило, Л. Березівська, Г. Білавич, О. Бондар, О. Драч, 3. Нагачевська, С. Попиченко, I. Улюкаєва, А. Січкар, О. Сухомлинська; внесок окремих персоналій у розвиток дошкільного виховання взагалі та організацію питань трудового виховання дітей дошкільного віку зокрема вивчали Т. Василенко, О. Венгловська, О. Джус, О. Зайченко, Г. Іванюк, Т. Куліш, О. Пшеврацька, A. Січкар, О. Сухомлинська.

Вихідні методологічні положення дослідження ідей трудового виховання дітей дошкільного віку у вітчизняній педагогічній думці грунтуються на здобутках украӥнських учених таких, як: О. Адаменко, О. Анішенко, Л. Березівська, Н. Гупан, Н. Дічек, Г. Іванюк, Я. Калакура, Є. Коваленко, Г. Корнетов, Д. Раскін, О. Сухомлинська. Однак, проведений аналіз свідчить, щзо питання підготовки кадрів дошкільного профілю до організації трудового виховання дітей у кінц̧і XIX - першій половині XX століття спеціально не вивчалися науковиями.

Установлено, щзо розвиток питань підготовки дошкільних працівників до організації трудового виховання дітей у досліджуваний період був зумовлений низкою чинників, а саме: соціально-політичними та соціальноекономічними умовами розвитку України, проведенням з’їдів з питань організачї народної освіти, розширенням мережі дошкільних закладів, заснуванням педагогічних курсів та Фребелівського інституту, виданням першого журналу з дошкільного виховання, відкриттям закладів для дітейсиріт та жіночих недільних шкіл, підвищенням рівня жіночої освіти, формуванням державної системи піклування про дітей дошкільного віку, розробкою спеціальних педагогічних рекомендацій для вихователів, 
створенням Товариства народних дитячих садків, прийняттям низки урядових постанов та наказів.

Ключові слова: підготовка, дошкільні прачівники, організація, трудове виховання, діти дошкільного віку.

Yakovenko $V . V$. Training preschool workers for the organization of labor education of children (the end of the XIX ${ }^{\text {th }}$ - the first half of the $X X^{\text {th }}$ century). The article analyzes the factors that influenced the preparation of preschool workers for the organization of labor education of children in the period of the end of the XIX $X^{\text {th }}$ - the first half of the $X X^{\text {th }}$ century. It has been revealed that certain theoretical and methodological aspects of this problem were disclosed in the scientists' works. The question of the continuity of labor education of preschool and elementary school age children was studied by A. Bohush, Z. Borysova, H. Lublinska, M. Mashovets, O. Proskura, O. Savchenko; different aspects of the development of preschool education and elementary school were studied by N. Antonets, O. Barylo, L. Berezivska, H. Bilavych, O. Bondar, O. Drach, Z. Nagachevskaya, S. Popychenko, I. Uliukaieva, A. Sichkar, O Sukhomlynska; the contribution of some scholars to the development of preschool education in general and to the organization of labor education of preschool children were studied in particular by T. Vasylenko, O. Venhlovska, O. Dzhus, O. Zaichenko, H. Ivanyuk, T. Kulish, O. Psevrazka, A. Sichkar, O. Sukhomlynskaya.

The initial methodological provisions of the study of the ideas of labor education of preschool children in the national pedagogical thought are based on the achievements of such Ukrainian scholars as: O. Adamenko, O. Anishchenko, L. Berezivska, N. Hupan, N. Dichek, H. Ivanyuk, Ya. Kalakura, Ye. Kovalenko, H. Kornetov, D. Raskin, O. Sukhomlynska. However, the analysis shows that the issues of training preschool workers to the organization of labor education of children at the end of the XIX ${ }^{\text {th }}$ - the first half of the $X X^{\text {th }}$ century were not specifically studied by scholars.

It has been established that the development of the issues of preparing preschool workers for the organization of labor education of children during the study period was determined by a number of factors, namely: socio-political and socio-economic conditions of the development of Ukraine, congresses on issues of the organization of public education, expansion of the network of preschool institutions, the establishment of pedagogical courses and the Freibean Institute, the publication of the first journal on preschool education, the opening of institutions for orphans and women Sunday schools, the increase of the level of women education, formation of the state system of care for preschool children, developing special pedagogical guidelines for teachers, the creation of the Association of public kindergartens, adoption of a number of government regulations and orders.

Keywords: training, preschool workers, organization, labor education, preschool children. 
Вступ. Інноваційні процеси, що відбуваються в сучасній Україні, творення нової української школи й освіти потребують осмислення вітчизняної педагогічної думки попередніх періодів. Значний інтерес у цьому аспекті становлять ідеї підготовки дошкільних працівників щодо трудового виховання дітей дошкільного віку кінця XIX - першої половини XX століття.

Окремі теоретичні й методичні аспекти зазначеної проблеми розкрито в працях науковців. Так, питання наступності трудового виховання дітей дошкільного та молодшого шкільного віку вивчали А. Богуш, 3. Борисова, Г. Люблінська, М. Машовець, О. Проскура, О. Савченко; різні аспекти розвитку дошкільного виховання та початкової школи досліджували Н. Антонець, О. Барило, Л. Березівська, Г. Білавич, О. Бондар, . Драч, 3. Нагачевська, С. Попиченко, I. Улюкаєва, А. Січкар, О. Сухомлинська; внесок окремих персоналій у розвиток дошкільного виховання взагалі та організацію питань трудового виховання дітей дошкільного віку зокрема вивчали Т. Василенко, О. Венгловська, О. Джус, О. Зайченко, Г. Іванюк, Т. Куліш, О. Пшеврацька, А. Січкар, О. Сухомлинська.

Вихідні методологічні положення дослідження ідей трудового виховання дітей дошкільного віку у вітчизняній педагогічній думці грунтуються на здобутках українських учених таких, як: О. Адаменко, О. Аніщенко, Л. Березівська, Н. Гупан, Н. Дічек, Г. Іванюк, Я. Калакура, Є. Коваленко, Г. Корнетов, Д. Раскін, О. Сухомлинська. Однак, проведений аналіз свідчить, що питання підготовки кадрів дошкільного профілю до організації трудового виховання дітей у кінці XIX - першій половині XX століття спеціально не вивчалися науковцями.

Мета статті - проаналізувати провідні чинники, які вплинули на підготовку дошкільних працівників до організації трудового виховання дітей в досліджуваний період.

Методи дослідження. Для розв'язання висунутої мети використовувалися такі методи, як: а) аналіз, синтез, порівняння, 
класифікація, узагальнення - для аналізу змісту першоджерел, визначення вихідних теоретико-методологічних позицій та з'ясування питань підготовки дошкільних працівників до трудового виховання дітей в кінці XIX - на початку XX століття; б) порівняльно-історичний метод - для виявлення чинників, що вплинули на підготовку дошкільних кадрів до трудового виховання дітей у досліджуваний період.

Використання означених методів дозволило отримати достатньо об’єктивну інформацію з проблеми дослідження.

Результати. Як свідчить узагальнення науково-педагогічних матеріалів, у кінці XIX - першій половині XX століття в Україні відбувається стрімкий розвиток усіх галузей суспільства, об’єднання зусиль державних та громадських організацій 3 метою забезпечення висококваліфікованими кадрами як промислового виробництва, так і сільського господарства та галузі освіти. Саме в цей період відкриваються перші жіночі школи в губерніях, кардинально змінюється думка про місце жінки в суспільстві, посилюється громадська активність у справі відкриття жіночих закладів освіти; проводяться державні реформи у галузі освіти жінок.

Однак, незважаючи на офіційний дозвіл відкриття жіночих шкіл, влада не турбувалась про матеріальний бік проблеми. 3 огляду на це, у $60-70$ ті pp. ХІХ століття відкриттям жіночих навчальних закладів почали займатися жінки-меценатки.

Зокрема, у зазначений період 3 метою підготовки фахівців до організації трудового виховання дітей дошкільного віку почали масово відкриватися жіночі недільні школи, які призначалися для жінок різного віку та соціального стану. Так, у Харківській губернії Х. Алчевською була заснована приватна жіноча недільна школа. У 1860 р. з’явилась перша та єдина на території Харківської губернії Маріїнська гімназія (Radist pedahohatvoptsia, 1966). 
Слід зазначити, що в кінці ХІХ століття провідну роль у підготовці дошкільних працівників до організації трудового виховання дітей відіграли земства, приватні особи, товариства.

Міська влада піклувалися про професійну освіту населення, про дошкільне та позашкільне виховання особистості. У 70 - 80-х роках XIX століття у містах були створені думи й управи, які дбали про розвиток народної освіти, про підготовку кадрів дошкільного профілю (Radist pedahoha-tvoptsia, 1966).

Для 80-х - 90-х pp. ХIX ст., взагалі було характерним активне формування державної системи піклування про дітей дошкільного віку; залучення дошкільних працівників до отримання освіти та професійної діяльності (Rozhvytok doshkilnoho vykhovannia na Kharkivshchini, 1955; Manuilova V. P., 1993; Ruzavin H. I., 2009).

Підгрунтям для розвитку питань підготовки дошкільних працівників до організації трудового виховання дітей в цей період стали позитивні зрушення в педагогічній галузі, які були пов'язані зі створенням та підтримкою освітніх закладів, зокрема дитячих садків, котрі функціонували при заводах i фабриках.

У 80-х - 90-х рр. ХІХ ст. якісній підготовці дошкільних працівників до організації трудового виховання дітей сприяло видання спеціальних педагогічних збірників для вихователів, де пропонувалися розробки виховних бесід із дітьми дошкільного віку на городі, у саду, полі, на річці тощо.

Для підвищення якості дошкільної освіти взагалі та підготовки дошкільних працівників до організації трудового виховання дітей, зокрема, у дитячих благодійних закладах, закладах для поширення грамотності серед місцевого населення та при виховних будинках відкривалися бібліотеки.

Отже, важливою подією визначених років було заснування педагогічних курсів для дошкільних працівників, відкриття дошкільних закладів, започаткування при виховних будинках бібліотек, видання 
спеціальних педагогічних збірників для вихователів, де пропонувалися розробки з трудового виховання дітей дошкільного віку тощо.

Установлено, що у період, який вивчається, велику роль у розв’язанні проблеми підготовки дошкільних працівників до організації трудового виховання дітей відіграло Відомство установ імператриці Марії. У 1894 році вийшов спеціальний наказ про заохочення церкви до справи відкриття при ній дитячих садків та організацію трудового виховання дітей у цих закладах.

Велику роль у розповсюдженні ідеї підготовки дошкільних працівників до організації трудового виховання дітей відіграли педагогічні товариства, які були створені в кінці XIX - у першій половині XX століття у м. Києві. До подібних товариств належали Київське товариство народних дитячих садків та Фребелівське педагогічне товариство. Завдяки їхній плідній діяльності Україна на початку XX століття стала центром підготовки дошкільних працівників взагалі та до організації трудового виховання дітей зокрема.

Звертаючись до діяльності Фребелівського товариства в окреслений період у контексті проблеми підготовки дошкільних працівників до організації трудового виховання дітей, слід відзначити, що в 1890 році Фребелівське товариство брало участь в організації першої Всеросійської виставки іграшок, що відбулась у Петербурзі. На цій виставці були представлені вітрини з іграми, конспектами занять і роботами дітей дошкільного віку (брали участь 7 дитячих садків).

А вже у 1896 році Фребелівське товариство брало участь у виставці, на якій були представлені дитячі ручні праці, друковані видання товариства, пояснювальні записки 3 відомостями про діяльність дитячого садка товариства.

Слід наголосити на тому, що у 1900 року Фребелівське Товариство було відзначено на Всесвітній педагогічної виставці у Парижі, де були представлені ручні роботи дитячих садків, фотоальбоми про трудову діяльність дітей дошкільного віку, звіти товариства. 
Як свідчить проведене дослідження, у кінці XIX - на початку XX століття активізували свою діяльність різноманітні організації з піклування про дітей дошкільного віку та безкоштовні народні дитячі садки. Зріс попит і на «фребелічок». До Фребелівського товариства з різних міст України часто зверталися 3 питаннями підготовки жінок до організації трудового виховання дітей дошкільного віку, надсилання матеріалів 3 організації зазначеного виховання (програми ігор та занять).

Так, у 1901 році до товариства звертались інспектори народних училищ із проханням надіслати статути дитячих садів, інструкції до ігор і занять 3 організації трудового виховання дітей дошкільного віку, рекомендації досвідчених осіб, які займалися цими питаннями. Подібні запити робили й окремі земські начальники та директори виправних колоній для неповнолітніх.

Необхідно звернути увагу і на те, що питання підготовки дошкільних працівників до організації трудового виховання дітей дошкільного виховання в кінці XIX - на початку XX століття розглядалися і на з’їздах із народної освіти. Наприклад, зазначені питання порушувались на I й II з'їздах діячів із технічної освіти в доповіді К. Цируля та А. Катаєва.

На III з'їзді (1904р.) Голова Фребелівського товариства у Петербурзі О. Клокова представила доповідь «Про дитячі садки в Росії» в якій звернула увагу на необхідність: поширення інформації про організацію трудового виховання у дитячих садках (читання лекцій, видання книг із трудового виховання, відкриття нових дитячих садків при жіночих гімназіях i вчительських семінаріях тощо); забезпечення тісної взаємодії дитячих садків iз родиною 3 питань трудового виховання дошкільників (організація виховательками дитячого садка періодичних зборів батьків); відкриття безкоштовних дитячих садків для дітей бідноти.

Як відомо, у 1907 році Товариство заснувало Фребелівський педагогічний інститут - вищий навчальний заклад із підготовки керівниць для дитячих садків. Співробітники Фребелівського педагогічного інституту в 
Києві внесли багато нового в розробку питань підготовки дошкільних працівників до організації трудового виховання дітей. Вони частково використали досвід Фребелівських курсів, які існували в Петербурзі, а також семінарій із підготовки кадрів дошкільного профілю Німеччини.

Варто також наголосити на тому, що до досвіду зарубіжних колег вітчизняні фахівці ставилися досить критично, пропонуючи більш прогресивні й науково обгрунтовані підходи. Наприклад, якщо упедагогічних закладах Німеччини значну увагу приділяли навчанню методики проведення фребелівських ігор та занять, то в педагогічному інституті провідне місце відводили вивченню дитини, особливостей іiі розвитку, фізичних можливостей, що, безумовно, вимагало високого рівня кваліфікації та загальної обізнаності дошкільних працівників.

Поряд із відкриттям педагогічного інституту, в 1911 році на його базі були організовані загальноосвітні курси для дошкільних працівників. На зазначених курсах велика увага приділялась практичній психологопедагогічній підготовці кадрів дошкільного профілю та проводилося педагогічне обстеження дітей.

3 метою підготовки дошкільних працівників до організації трудового виховання дітей у квітні 1915 року Фребелівським педагогічним інститутом і Товариством були засновані шеститижневі вечірні курси, а з 1916 року при інституті почали функціонувати вечірні курси з позашкільної освіти для осіб жіночої й чоловічої статі.

Важливою подією окресленого періоду було також створення Товариством народних дитячих садків курсів із дошкільного виховання. Положення Статуту курсів були спрямовані на підвищення статусу дошкільних працівників й мали на меті заохотити їх до отримання педагогічної освіти.

Значну роль у підготовці дошкільних працівників до організації трудового виховання дітей відіграли також влаштовані Товариством виставки «Дошкільне виховання» (1908 рік) і «Дитяча праця» (1910 рік). На 
зазначених виставках експонувалися праці дітей, дитячі книги, іграшки, посібники та обладнання для дитячих садків, організовувалися ігри та читалися лекції і заслухувались доповіді з питань теорії та практики трудового виховання маленьких дітей. Це були перші в Україні виставки такого типу, які в подальшому суттєво вплинули на підготовку кадрів до організації трудового виховання дітей дошкільного віку (Stupak F. Ya., 1997).

Визначаючи одним із своїх завдань пропаганду ідей підготовки дошкільних кадрів до трудового виховання дітей, правильного виховання дошкільників узагалі, Київське товариство народних дитячих садків заснувало спеціальний журнал. Організація його була нелегкою справою (Stupak F. Ya., 1997).

Ще до відкриття 2-ої виставки «Дитяча праця» Київське Товариство почало усвідомлювати, що виставки, лекції, збори - це все тимчасові заходи. Потрібна безперервна i широка пропаганда в цьому напрямі, i найбільш могутнім засобом може бути друковане слово. Із січня 1911 року зазначене Товариство почало видавати журнал «Дошкільне виховання», який швидко набув популярності серед дошкільних працівників, бо розповсюджував інформацію про нагальні потреби народних дитячих садків та організацію трудового виховання в них і був єдиним періодичним виданням, котре повністю на своїх сторінках розглядало питанням дошкільного виховання (Stupak F. Ya., 1997).

Отже, наявність спеціального друкованого видання активно сприяла підготовці дошкільних працівників до організації трудового виховання дітей.

Після перемоги Великої Жовтневої соціалістичної революції (1917 рік) почала створюватися розгалужена мережа закладів дошкільної освіти. У серпні 1920 року на Другій Всеукраїнській нараді з освіти було затверджено розгалужену систему педагогічної освіти. Зокрема, факультети соціального виховання Інститутів народної освіти почали готувати кваліфікованих «соцвихівців», здатних упроваджувати в життя систему соціального виховання особистості в повному іiі обсязі та змісті, охоплюючи увесь 
дитячий вік. Таким чином, потреба у висококваліфікованих кадрах дошкільного профілю була нагальною.

Перед керівництвом України гостро постало питання відкриття нових дитячих установ. Завдяки активній підтримці держави до кінця 1921 року основним типом дошкільних закладів став дитячий садок. Доцільно підкреслити, що окрім дитячих садків, існували й інші форми суспільного дошкільного виховання - дитячі літні та зимові майданчики, дошкільні групи, вечірні дитячі кімнати при клубах.

Саме в 20-ті pp. ХХ століття почали відкриватися дитячі садки й сезонні дитячі майданчики в селах. Однак, наприкінці 1921 року кількість дітей у дитячих садках суттєво зменшилася, що пояснюється тим, що дітисироти були переведені до дитячих будинків. Відокремлення дітей-сиріт від дітей, які мали родину, зумовлювало різний рівень підготовки дошкільних працівників, адже методика й практика виховання таких дітей мала свої відмінності, які обов’язково повинні були знати кадри дошкільного профілю.

У 1924 році була проведена Всеукраїнська нарада завідувачів губернськими відділами соціального виховання, котра рекомендувала взяти під особливий контроль справу трудового виховання дітей дошкільного віку, розгорнути роботу серед населення щодо відкриття нових дошкільних закладів. Це сприяло виникненню потреби у збільшенні кількості дошкільних кадрів та підвищенні рівня їхньої підготовки.

Важливе значення для поліпшення діяльності дошкільних установ взагалі та організації трудового виховання дітей дошкільного віку зокрема мала розробка проекту програми діяльності дитячого закладу. Перший проект такої програми був виданий у 1932 році. Укладачі програми намагалися врахувати вікові особливості дітей, особливо при організації трудового виховання, а дошкільним працівникам радилось підвищувати свій професійний рівень та реалізовувати свої здібності й таланти при організації виховного процесу. 
Вагоме значення для подальшого розвитку питань підготовки дошкільних працівників до організації трудового виховання дітей мала Постанова «Про заходи щодо упорядкування роботи дитячих садків» (1935 рік). Згідно з зазначеною постановою встановлювався 9-годинний робочий день дитячих садів. Якщо була така необхідність, рекомендувалося збільшити часи роботи дитячого садка до $14-15$ годин.

Усе це вимагало вдосконалення професійних знань i навичок дошкільних працівників. Зокрема, від дошкільних кадрів вимагалось володіння умінням добре організувати роботу з батьками та громадськістю, мати високу педагогічну майстерність, постійно підвищувати свій професійний рівень, брати активну участь у громадській роботі.

Для передачі та широкої пропаганди кращого досвіду організації трудового виховання дітей із 1932 року при дитячих садках почали відкриватися методичні кабінети. Так, за п’ять років подібні кабінети були відкриті у 28 областях і республіках. У 1937 році їх налічувалося близько 200.

У 1938 році були розроблені статут і запропоновані методичні рекомендації для вихователів закладів дошкільної освіти під назвою «Керівництво для вихователя дитячого садка». До складання та обговоренню зазначеного документу було залучено досвідчених вихователів, методистів, науковців. Відповідно до статуту дошкільного закладу завідувач дитячого садка й вихователі повинні були мати спеціальну педагогічну освіту.

Розглядаючи розвиток питань підготовки дошкільних працівників до організації трудового виховання дітей у 50-ті рр. ХХ століття, варто зазначити, що саме в цей період в Україні відбувалося колгоспне будівництво, яке потребувало створення на селі широкої мережі дитячих садків та дитячих майданчиків, що, в свою чергу, потребувало підготовки досвідчених вихователів.

3 огляду на це, особлива увага приділялася курсам із підготовки працівників колгоспних дошкільних майданчиків. Для організації курсів в 
Україні в кожному районі була створена спеціальна комісія із представників відділів народної освіти, охорони здоров'я та сільського господарства. Зазначена комісія затверджувала план підготовки завідувачів та вихователів закладів дошкільної освіти, визначала потребу в цих кадрах у кожному районі, а також затверджувала персональний склад слухачів курсів.

У подальшому українським урядом були прийняті рішення, які сприяли поліпшенню дошкільної справи, упорядкуванню мережі дошкільних установ, встановленню чіткої роботи дитячих садків, визначенню дитячого садка основним типом дошкільної установи, зміцненню його матеріальної бази, упорядкуванню фінансування, норм витрат, створенню можливостей для поширення мережі дитячих садків та майданчиків, будівництву нових типів дитячих закладів, підготовці кадрів дошкільного профілю, вдосконаленню організації трудового виховання дітей дошкільного віку.

Обговорення. Проведене дослідження дозволило доповнити чинники, які сприяли розвитку питань підготовки дошкільних працівників до організації трудового виховання дітей у кінці XIX - на початку XX століття.

Висновки. Отже, розвиток питань підготовки дошкільних працівників до організації трудового виховання дітей у досліджуваний період був зумовлений низкою чинників, а саме: соціально-політичними та соціальноекономічними умовами розвитку України, проведенням з’їздів з питань організації народної освіти, розширенням мережі дошкільних закладів, заснуванням педагогічних курсів та Фребелівського інституту, виданням першого журналу з дошкільного виховання, відкриттям закладів для дітейсиріт та жіночих недільних шкіл, підвищенням рівня жіночої освіти, формуванням державної системи піклування про дітей дошкільного віку, розробкою спеціальних педагогічних рекомендацій для вихователів, створенням Товариства народних дитячих садків, прийняттям низки урядових постанов та наказів. 
Розвиток дошкільного виховання на Харківщині. Дошкільне виховання. 1955. № 11. С. 20.

Российская педагогическая энциклопедия. Под ред. В. П. Мануйлова. М. : Большая российская энциклопедия, 1993. $1376 \mathrm{c.}$

Рузавин Г. И. Методология научного познания : учеб. пособие. М. : ЮНИТИ-ДАНА, 2009. $287 \mathrm{c}$.

Ступак Ф. Я. Діяльність благодійних товариств Києва другої половини XIX - початку XX століття : автореф. дис. ... канд. іст. наук : 07.00.01. К., 1997. 23 с.

\section{REFERENCES:}

Radist pedahoha-tvoptsia (1966). [Joy of the creator teacher]. Doshkilne vykhovannia. 11. 21-22 (in Ukranian).

Rozhvytok doshkilnoho vykhovannia na Kharkivshchini (1955). [Development of preschool education in the Kharkiv region]. Doshkilne vykhovannia. 11. 20 (in Ukranian).

Manuilova V. P. (Ed.) (1993). Rossiiskaia pedahohicheskaia entsyklopediia [Russian Pedagogical Encyclopedia]. Moskva : Bolshaia rossiiskaia entsyklopediia (in Russian).

Ruzavin H. I. (2009). Metodolohiia nauchnoho poznaniia. [Methodology of scientific knowledge]. Moskva : Yuniti-Dana (in Russian).

Stupak F. Ya. (1997). Diialnist blahodiinykh tovarystv Kyiva druhoi polovyny XIX - pochatku $X X$ stolittia. [Activities of charitable associations of Kyiv in the second half of the XIX and early XX centuries] (Abstract of candidate's thesis). Kyiv, Ukraine (in Ukranian).

\begin{tabular}{|c|c|}
\hline Інформація про автора: & Information about the author: \\
\hline Яковенко Віта Валеріївна: ORCID: & Yakovenko Vita Valeriivna: ORCID: \\
\hline http://orcid. & http://orcid.org/0000-0003-3826-037X; \\
\hline викладач кафедри теорії та методики & Department of Theory and Method of \\
\hline дошкільної освіти Комунального закладу & Education \\
\hline гуманітарно-педагогічна & Humanitarian- \\
\hline академія» Харківської обласної ради, & Pedagogical Academy» of Kharkiv Region \\
\hline $\begin{array}{l}\text { провулок Руставелі, 7, м. Харків, Україна } \\
61000\end{array}$ & $\begin{array}{l}\text { Council, Rustaveli lane, 7, Kharkiv, Ukraine } \\
61000\end{array}$ \\
\hline e-mail: vita.val2017@ukr.net & e-mail: vita.val2017@ukr.net \\
\hline
\end{tabular}

Цитуйте цю статтю як: Яковенко В.В. Підготовка дошкільних працівників до організації трудового виховання дітей (кінець XIX - перша половина XX ст.). Теорія та методика навчання та виховання. 2019. № 46. C. 192-204. DOI: 10.34142/23128046.2019.46.15

Дата надходження статті до редакції: 16.04.2019

Стаття прийнята до друку: 30.04.2019 